\title{
Bioactive natural products from Thai plants
}

\author{
Chulabhorn Mahidol, Poolsak Sahakitpichan and Somsak Ruchirawat \\ Chulabhorn Research Institute, Bangkok, Thailand \\ Chulabhorn Research Centre, Mahidol University, Bangkok, Thailand
}

\begin{abstract}
.
The investigation of Thai medicinal plants for the potential therapeutic agents is surveyed with a particular emphasis on the search for antimalarial agents. The study on Diospyros mollis, Croton sublyratus, and Phyllanthus amarus is described.
\end{abstract}

Thailand is uniquely located to represent the fauna and flora which characterizes the biogeographic province of Indo-Burma. A number of the eastern Himalaya temperate taxa penetrate south into the northern mountains of Thailand while the southern part is evergreen forest thus making this area one of the richest floristic regions of the world (1). It has been estimated that the vascular plants in Thailand are not less than 10,000 species of about 1,763 genera from 245 families (2). The numbers of alkaloidcontaining plants are estimated to be only about 266 species of 176 genera in 67 families based on the Thai plants names and parts of the uncompleted flora of Thailand (3).

The potential of natural products as therapeutic agents in the treatment of malaria is enormous. Quinine was introduced as an antimalarial for more than a century ago. Quinine also served as a prototype as an antimalarial leading to the discovery of synthetic antimalarials based on the quinoline compounds. 4and 8-Aminoquinoline derivatives have proved their efficacy as antimalarials. Mefloquine, a quinoline methanol derivative, has recently been introduced as an antimalarial.

The Chinese has a long history of use of a herb called Qing hao (Artemisia annua) for the treatment of malaria. The pure compound was isolated in 1972 and named Qinghaosu (QHS) or Arteannuin meaning the "active principle of Qing hao"(4)

In Thailand, interests for the use of herbal medicine for the treatment of malaria has been long standing. Lately many groups of Thai scientists have been working on various plants to scrutinize the validity of these 'claims' as well as searches for new antimalarial agents from plants. During the second world war, Professor Ketusingh attempted to use 30 herbal medicine to treat malaria. The treatments were applied to 543 patients with infections with $P$. falciparum (255 patients) and $P$. vivax. (288 patients)(5). From the study the plant of Oroxylum indicum showed the total cure rate as high as $65.7 \%$ and it is very interesting to note the definite preference for the plants of Azadirachta and Nyctanthes arbor-tritis for the treatment of those patients infected with $P$. vivax 
Scientists at Division of Medical Research, Department of Medical Sciences, Ministry of Public Health and at AFRIMS (Armed Force Research Institute for Medical Science) have been interested in the search for antimalarial agents from Thai medicinal plants (6).

After screening many plants, the four plants (Brucea javanica, Picrasma javanica, Celastrus paniculatus, and Tiliacora triandra) which exhibited the minimal inhibitory concentration (MIC) of not more than 25 microgram per millilitre were then further studied by extraction with various solvents, each solvent extract was then again tested. The chloroform extracts gave the best result for the in-vitro antiplasmodial activity for Brucea javanica, Picrasma javanica and Celastrus paniculatus. In the case of Tiliacora triandra, the water insoluble alkaloid fraction gave the best results. The four active fractions were then subjected to various chromatographic techniques to isolate pure compounds for further testing.

Twelve quassinoids have been isolated from $B$. javanica fruits and the structures have been elucidated. These quassinoids could be divided into 4 groups with mainly different functionalities in the $A$ ring. In group I, there are seven compounds isolated with varying ester substituents, 2 compounds were isolated with structures as shown in group II and only one compound was isolated having the structure as shown in group III and finally two compounds with the glycoside groups were isolated as classified in group IV.

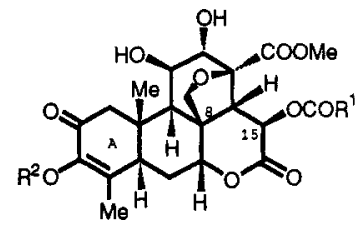

I

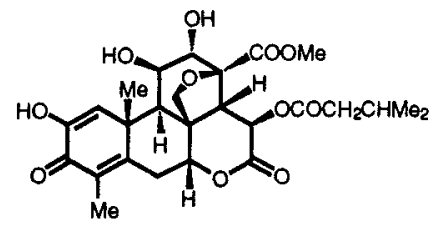

III

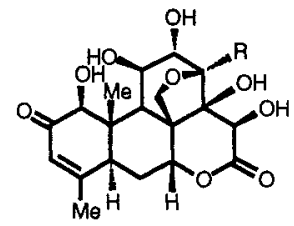

II

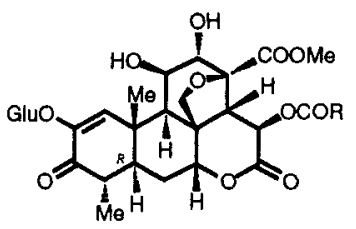

IV

Bruceatin exhibited a very impressive IC 50 at $0.0008 \mathrm{mg} / \mathrm{ml}$. The most active quassinoids were found to belong to the type I with only the variation of the side chain of the ester grouping.

Other plants of Eurycoma longifolia, Ailanthus altissima and Simarouba amara have also been investigated and related compounds have been isolated and identified $(7,8,9)$. The IC50 of the 9 compounds isolated from these plants ranged from $0.004 \mathrm{mg} / \mathrm{ml}$ to $1.15 \mathrm{mg} / \mathrm{ml}$.

From Picrasina javanica, two carbazole alkaloids were isolated and identified to be 4-methoxy-1vinyl- $\beta$-carboline derivatives with the IC50 2432.3 and $3280.5 \mathrm{ng} / \mathrm{ml}$ (10).

From Celastrus paniculatus, Pristimerin, a pentacyclic terpene was isolated and the IC50 was found to be $280 \mathrm{ng} / \mathrm{ml}$ (11).

From Tiliacora triandra, three bisbenzylisoquinoline alkaloids were isolated and identified to be Tiliacorinine with a IC $503533 \mathrm{ng} / \mathrm{ml}$, Tiliacorine with a IC $50675 \mathrm{ng} / \mathrm{ml}$ and Nor-Tiliacorinine A, with a IC $50558 \mathrm{ng} / \mathrm{ml}$. Two more alkaloids, coded alkaloid $\mathrm{G}$ and alkaloid $\mathrm{H}$ were also isolated but the structures 
were at present unknown. The IC 50 of alkaloids $\mathrm{G}$ and $\mathrm{H}$ were found to be 344 and $916 \mathrm{ng} / \mathrm{ml}$ respectively (12).

Azadirachta indica var. siamensis has also been used for the treatment of malaria, interestingly the same practice was also adopted in Nigeria. Nimbolide, a bitter principle, was isolated as the main constituent of this plant and the structure was deduced to be pentacyclic lactone. The in vitro testing of the crude extract and the pure Nimbolide was investigated (13).

Another Thai plant that has been extensively studied is Diospyros mollis. Fresh berries of Diospyros mollis have long been used effectively against intestinal hook-worm infestation. The anti hookworm property of the Diospyros mollis berries was scientifically tested (14). The chemistry of the active principle of Diospyros mollis berries has also been extensively investigated (15-18).

As far as the discovery of drug from the plants of Thailand is concerned the highlight must be the discovery of Plaunotol from Plao-Noi [Croton sublyratus Kurz (Euphorbiaceae)] by the Japanese scientists at Sankyo company. The structure of the compound was proved to be the diterpene by spectroscopic method and synthesis (19). The compound was proved to be a potent antipeptic ulcer drug and it is now commercially available under the trade name of Kelnec.

We have recently investigated the plant Phyllanthus amarus Schum.\&Thonn.(Euphorbiaceae) (20) locally known as Look Tai Bai Phyllanthus amarus has been traditionally used for the treatment of jaundice and other diseases. Although the anti-hepatotoxic potential of the plant has been controversial, the major chemical components were known to be phyllanthin and hypophyllanthin. Complete ${ }^{1} \mathrm{H}$-nmr data and unambiguous assignments of the ${ }^{13} \mathrm{C}$-nmr spectra of phyllanthin and hypophyllanthin were obtained using combinations of $1 \mathrm{D}$ and 2D nmr techniques. The absolute configuration of hypophyllanthin was determined by using circular dichroism technique. Both phyllanthin and hypophyllanthin were evaluated for cytotoxic activity with a battery of cultered mammalian cells but no significant cytotoxic activity was observed for these compounds. However, interestingly, both compounds enhanced the cytotoxic response mediated by vinblastine with multidrug-resistant KB cells. Moreover, phyllanthin was found to displace the binding of vinblastine with membrane vesicles derived from this cell line, suggesting an interaction with the P-glycoprotein.

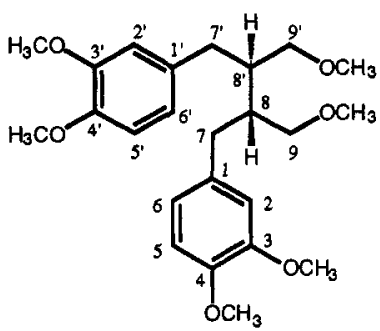

PHYLLANTHIN

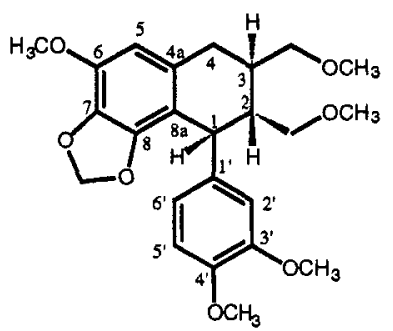

HYPOPHYLLANTHIN

Acknowledgment: We are grateful to the Thai Government and Petroleum Authority of Thailand for generous financial support of our research. 


\section{REFERENCES}

1. P. S. Ashton, in "Biodiversity in Thailand" edited by S. Wongsiri and S. Lorlohakarn, Prachachon Ltd. Co. Bangkok. 1989, p. 51-58.

2. T. Santisuk, in "Biodiversity in Thailand" edited by S. Wongsiri and S. Lorlohakarn, Prachachon Ltd. Co. Bangkok. 1989, p. 81-90.

3. B. Tantisewie and S. Ruchirawat, in " The Alkaloids, Chemistry and Pharmacology" Volume 41 edited by A. Brossi and G.A. Cordell, Academic Press 1992, p. 1-40; T. Smitinand, "Thai Plant Names" Funny Publishing Ltd. Bangkok. 1980.

4. For a review see: D.L. Klayman, Science 1985, 228, 1049-1055.

5. O. Ketusingh, in "Special Publication for the 60th Anniversary of Siriraj Hospital, 1950, 275-281.

6. T. Dechatiwongse, paper presented at a seminar on "Herbal Medicine and Malaria" November 1989; organizer: The Ministry of University Affairs

7. J.D. Phillipson, M.J. O'Neill, and D.C. Warhurst, Proceedings of The First Princess Chulabhorn Science Congress 1987, International Congress on Natural Products V. 2, 55-68.

8. For a review see: J.D. Phillipson and M.J. O'Neill, Parasitol. Today 1986, 2, 355-358.

9. K. Pavanand, W. Nutakul, T. Dechatiwongse, K. Yoshihira, K. Yongvanitchit, J.P. Scovill, J.L. Flippen-Anderson, R. Gilardi, C. George, P. Kanchanapee, and H.K. Webster, Planta Med. 1986, 2, 108-111.

10. K. Pavanand, K. Vongvanitchit, H.K. Webster, T. Dechatiwongse, W. Nutakul, Y. Jewvachdamrongkul, and J. Bansiddhi, Phytother. Res. 1988, 2, 33-36.

11. K. Pavanand, H.K.Webster, K. Yongvanitchit, A. Kun-anake, T. Dechatiwongse, W. Nutakul, and J. Bansiddhi, Phytother. Res. 1989, 3, 136-139.

12. T. Dechatiwongse, P. Chavalittumrong, W. Nutakul, Bull. Dept. Med. Sci. 1987, 29, 33-38.

13. S. Rochanakij, Y. Thebtaranonth, C. Yenchai, and Y. Yuthavong, Southeast Asian J. Trop. Med. Pub. Hlth. 1985, 16, 66-82.

14. E.H. Sadun and J. Vajrasthira, J. Parasit. 1954, 40-49.

15. J.W. Loder, S. Mongkolsuk, A. Robertson, and W.B. Whalley, J. Chem. Soc. 1957, 2233-2237.

16. K. Yoshira, S. Natori, and P. Kanchanapee, Tetrahedron Lett. 1967, 4857-4860.

17. L. Borsub, Y. Thebtaranonth, S. Ruchirawat, and C. Sadavongvivad, Tetrahedron Lett. 1976, 105 108.

18. S. Paphassarang, M. Becchi, and J. Raynaud, Tetrahedron Lett. 1984,523-526.

19. A. Ogiso, E. Kitazawa, M. Kurabayashi, A. Sato, S. Takahashi, H. Noguchi, H. Kuwano, S. Kobayashi, and H. Mishima, Chem. Pharm. Bull. 1978, 26, 3117-3123.

20. A. Somanabandhu, S. Nitayangkura, C. Mahidol, S. Ruchirawat, K. Likhitwitayawuid, H.Shieh, H Chai, J.M. Pezzuto, and G. A. Cordell, J. Nat. Prod. 1993, 56, 233-239 